\title{
The Civil Justice System and The Public: Highlights Of The Alberta Pilot
}

\author{
LOIS GANDER, DIANA LOWE AND MARY STRATTON
}

In 1999, the Canadian Forum on Civil Justice initiated the "Civil Justice System and the Public," a research program designed to study the state of communication between the civil justice system and the public and to develop practices to improve communication so that the public can become more involved in civiljustice reform. The goal of the project is to make specific and clear recommendations for effective change that will ultimately improve access to the civil justice system by increasing the ability of the system to hear, involve and respond to the public. Researchers from the Canadian Forum on Civil Justice and the University of Alberta are joined by parmers from across Canada in academia, the judician; the legal profession, court administration. public legal education agencies. community organizations, private consultonts and the public in a collaborative and multidisciplinary research alliance. The extensive partnership and our collaborative approach to the research are key to our "action research" design, which involves our partners in the draffing of research questions, data collection. analysis and dissemination. Through the active and engaged participation of our pariners. our findings are broadly known, understood and acled upon, ensuring that change is promoted through the process of conducting the research itself. This aricle ontimes the major features of the study and the findings. recommendations and conclusions arising out of the pilot study conducted in Alberta.
En 1999, le Forum canadien sur la justice civile a mis sur lancé "Le système de justice civile er le public ". un programme de recherche ayant pour but d'examiner l'état de la communication entre le système de justice civile el le public, et de développer des pratiques visam à améliorer la commmication afin que le public puisse participer plus activement dे la réforme de la justice civile. Le projet a pour bur de faire des recommandations précises el claires pour entamer in changement efficace qui améliorera lacce's au système de justice civile en aidant ce dernier à écouter le public. d̀ encourager sa participation et à réagir face à ce dernier. Dans un effort de recherche en parficipation ef pluridisciplinaire. des chercheurs du sur la justice civile et de I'Universite de I'Alberta se joignent à des chercheurs du milieu universilaire et à des membres de l'ordre judiciaire. de la profession d'avocat, de l'administration des tribunaux, d'organismes pour l'éducation juridigue des Canadiens, d'organismes communautaires. à des experis-conseils et au public des quatre coins du pays. L'envergure du partenarias et notre approche en participation à la recherche sont des éléments clés de notre objectif "recherche-action "qui engage nos partenaires dans l'élaboration de questions de recherche ainsi que dans la collecte. l'analyse ef la diffusion de donnes. Grace à la participation active et engagée de nos partenaires. nos conclusions sont diffusées, comprises et mises à exécution, assurant ainsi que le processus mème de recherche encourage le changement. Cet article donne les grandes lignes de l'étude, des recommandations et des conclusions firées de l'ciude pilote menée en Alberia.

The order of the authors is alphabetical and the authors contributed equally to this paper. Lois Gander is the Director of the Legal Studies Program, a Professor in the Faculty of Extension, University of Alberta and is a Research Director for the Civil Justice System and ihe Public, a collaborative research project funded by the Alberta Law Foundation and the Social Science and Humanities Council of Canada. Diana Lowe is the Executive Director of the Canadian Forum on Civil Justice and a Research Director for the project. Mary Stration is the Research Coordinator for the project. The present paper is only possible because of the contributions of many individuals. We wish to thank all of our partners and research participants for their contributions to the development of this project and the wealth of data it has generaled. Research Directors Lois Gander, Diana lowe, Teresa Rose and Justice June Ross have guided the project from its inception, and Barbara Billingsley has joined the Research Directors more recently. We thank each of the Research Directors for their comments on earlier drafts of this paper. We also wish to acknowledge the valuable contributions of the project Research Assistants: Amritha Fernandes-Bakshi, James Cresswell. Marisa Ferraiuolo, Naomi Schmold, Camron Schwartz. Graham Stat, Lily Tsui and Shannon Williams. 


\section{TABle of Contents}

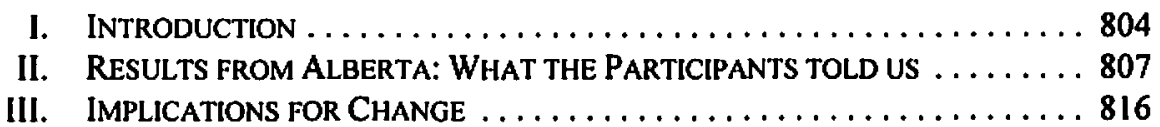

\section{INTRODUCTION}

The civil justice system is fundamental to the peaceable resolution of disputes arising in Canadian society. Divorce and family issues, consumer claims ranging from house purchases to car leases, professional service complaints, commercial and corporate disputes, concerns relating to government services or public entitlements and the enforcement of rights, such as the rights to equality and to privacy, are but a few reasons to invoke the civil justice system. But serious concerns have been raised from both inside and outside the civil justice system about public access to that system. There have been a number of significant studies of the civil justice systems in Canada and internationally in recent years.' Along with recommendations aimed at reducing costs and delay, each of these reports have included recommendations aimed at improving public understanding, promoting a greater user orientation and involving the public in reform initiatives.

The Canadian Bar Association (CBA) Task Force, the Ontario Civil Justice Review, the Manitoba Civil Justice Review Task Force ${ }^{2}$ and the British Columbia Justice Reform Committee ${ }^{3}$ primarily relied on public input obtained in the course of meetings and through written submissions. ${ }^{4}$ Other reform efforts limited their "public" consultation to meetings with, and submissions by, what might be characterized as the "legal professionals" such as lawyers, court administrators, legal aid providers, public legal educators and native court workers. The lack of evidence-based ${ }^{\text {s }}$ research in the context of these large-scale reform initiatives is not compensated for by a pre-existing body of work in this area. One reviewer noted that given "the limited range and scope of existing Canadian research, the conclusions

1 The major study in Canada was undertaken by the Canadian Bar Association Task Force on Systems of Civil Justice, Report of the Canadian Bar Association Task Force on Systems of Civil Justice (Ottawa: The Association, 1996), online:Canadian Bar Association <www.cba.org/CBN/cba_Reports/ pdI/systemscivil_tfreport.pdr> [Systems of Civil Justice Task Force]. There have also been provincial reviews: Ontario Civil Justice Review, Civil Justice Revieu: Supplemental and Final Reporl (Toronto: Ontario: Civil Justice Review, 1996); Manitoba, Civil Justice Task Force, Maniroba Civil Justice Review Task Force Report (Winnipeg: Government of Manitoba, 1996) [MCJRTF Report]; British Columbia, Ministry of Attomey General, Strategic Reforms of British Columbia 's Justice System (Victoria: Government of British Columbia, 1997) [B.C. 's Strasegic Reforms]; and intemational reviews, the best-known being the Woolf Report: Lord Woolf, Access to Justice: Final Report to the Lord Chancellor on the Civil Justice System in England and Wales (London: Her Majesty's Stationery Office, 1996).

MCJRTF Report, ibid.

B.C. 's Sirategic Reforms, supra note I.

The CBA also conducted a survey of individuals in community groups/organizations across Canada: Report: Survey on Civil Justice Reform (Public Survey) (Vancouver: Canadian Facts, 1996).

The term "empirical research" can include all kinds of quantitative and qualitative methodologies; however as it tends to be equated only with quantitative research in North America, we prefer to use the term "evidence-based." 
that can be drawn about public perceptions are both modest and tentative." Clearly, there is a need for an integrated and informed, evidence-based approach to understanding problems, identifying good practices and recommending social and legal changes, in order to improve the relationship between the civil justice system and the public. ${ }^{7}$

The Canadian Forum on Civil Justice was created in 1998 to pursue the agenda of civil justice reform in Canada. ${ }^{8}$ Recognizing the need to involve not only the justice community but also members of the public in the process of reform, the Forum has been working to find effective means of ensuring that the many interests and perspectives of the public are understood.9 In 1999, with a view to finding ways to increase public involvement in the system, the Forum initiated the "Civil Justice System and the Public" project, which is a national study of the state of communication between the civil justice system and the public. ${ }^{10}$

The research is led by the Canadian Forum on Civil Justice." Overall direction for the research rests with four Research Directors, who, together with the Research Coordinator, Mary Stratton, work as a Research Team responsible for the overall project management. The research has been conducted in the field by Mary Stratton and a number of student research assistants. The research is conducted in partnership with academic and community partners ${ }^{12}$ who provide advice and assistance regarding research design and methodology, access to the courts and other related service providers in the civil justice system, expertise in specific areas of the civil justice system, communication, organizational management and Aboriginal

- Sandra Wain, "Public Perceptions of the Civil Justice System" in Ontario Law Reform Commission, Rethinking Civil Justice: Research Studies for the Civil Justice Review, vol. 1 (Toronto: Ontario Law Reform Commission, 1996) 39 at 45.

, John D. McCamus, "Civil Justice Reform: What Do We Know?" in Jean Maurice Brisson \& Donna Greschner, eds., Public Perceptions of the Administration of Justice, 1995 (Montreal: Les Éditions Thémis, 1996) 395.

- The Canadian Forum on Civil Justice is a national organization, created as the result of a recommendation of the Canadian Bar Association's Systems of Civil Justice Task Force, which recognized the challenges facing our civil justice system and the need for an organization focused on improving the civil justice system. The Forum was established through a joint initiative of the Canadian Bar Association and the University of Alberta. Faculty of Law. The goal of the Forum is to bring together the public, the courts, the legal profession and government to strive to ensure that civil justice is accessible, effective, fair and efficient. There is no other organization in Canada with the mandalc to collect and share information and conduct research for the purpose of promoting reform of the civil justice system.

" The public interest in the civil justice system tends to arise through direct involvement in a legal dispute, and as such is fleeting and focused primarily on a specilic case rather than on the system as a whole. As a result, the public has tended not to be engaged in the process of reform.

The study has been funded by the Alberta Law Foundation, the Government of Canada's Department of Justice, the Social Sciences and Humanities Research Council of Canada, through its innovative Community University Research Alliance (CURA) program, and the University of Alberta.

"The Forum is uniquely positioned to bring together all of the interested partners for this collaborative effor, to coordinate the research project and to ensure that the research and program objectives are realized.

1: The research partners include the Canadian Forum on Civit Justice. the University of Alberta (Faculties of Law, Extension, Arts and the School of Native Studies), the Canadian Bar Association, the Association of Canadian Court Administrators, the Canadian Institute for the Administration of Justice, the Canadian Judicial Council, the Canadian Association of Provincial Court Judges, the Public Legal Education Association of Canada and member agencies. Justice Canada, the Canadian Centre for Justice Statistics, the Alberta Law Reform Institute, the Legal Aid Society of Alberta and the Yellowhead Tribal Community Corrections Society. 
communities. Our partners are engaged in a collaborative approach to research, which we have defined as follows: "working together in a cooperative, equitable and dynamic relationship, in which knowledge and resources are shared in order to attain goals and take action that is educational, meaningful and beneficial to all."13 It is understood by this definition that a) research is conducted with, and not on, the community and b) all collaborators have different but equally important knowledge and resources to both share with and gain from each other.

The focus of our research is on understanding and improving communication within the civil justice system and between the civil justice system and the public. We define communication as "including the active participation of all involved parties for the purpose of sharing knowledge by various means that include formal education and informal learning of all kinds. Imbedded in the process are various aspects which include informing the public about the civil justice system, communication between various components within the civil justice system, and interactive communication where the public communicates with the civil justice system."14

It is important to be clear on the terms we have used to define the research. While courts are a central and fundamental feature of the civil justice system, the system is broader than the courts themselves. We use the term "civil justice system" to include the individuals who work in and use the system and service providers outside of the courts but who are integral to the court system, including lawyers, legal aid, departments of justice, law reform organizations, legal academics, public legal educators, librarians and court-connected dispute resolution mechanisms.

When we speak of "the public" we recognize that we are not referring to a single, homogeneous group of citizens, but that the public is comprised of many individuals and groups with different social characteristics and needs. We include users and potential users of our civil justice system: those that the system was created to serve. For our interviews with the public we seek out users of the system, in the belief that those individuals who have had experience with the system (as plaintiffs, defendants, witnesses and jurors) will be best able to respond to our research questions.

There are four basic research questions:

1. What is the current state of communication between the civil justice system (broadly defined) and the public?

2. How is that communication experienced by

(a) people within the system with each other and with the public, and

(b) the public?

" "Working Document" at 3, online: Canadian Forum on Civil Justice <www.cfcj-fcjc.org/ working_dochtm>. This document continues to develop, but the current version of the Working Document is available online.

14 The definition of communication is found at page 5 of the "Working Document" (ibid.), which is a paper designed by the Research Team to describe the goals, philosophy and methodological approach of the research [emphasis added]. 
3. What can be done to improve communication between the civil justice system and the public?

4. In the process of answering the above questions, do other issues emerge that have import for other components of the justice system?

These questions are addressed by a combination of methods of gathering information, including key contact meetings, short questionnaires, in-depth interviews and observation notes. ${ }^{15}$ Key contact meetings are a first step in each jurisdiction. They serve a two-way information sharing purpose: the research team gains invaluable background information about the research community and key members of that community learn the details and purpose of the research first hand. Short questionnaires identify and provide facts and figures about important issues, but are limited in their ability to explain why things are the way that they are. The in-depth interviews fill this gap by encouraging participants to reflect upon and explore their knowledge and experience. Researcher observations add to the value and richness of both questionnaires and interviews by providing an additional perspective on the way things happen.

The interviews are our primary source of data. We use broad and neutral questions as a starting point for a conversation with participants about their experiences in communication between the civil justice system and the public. The role of the interviewer is to support the participants in this process by encouraging them to expand on what they have already said. The interview transcripts capture the way that people actually talk and think, illustrating multiple perspectives on communication issues that allow us to see nuances, overlaps and contrasting views around the same basic issue or theme.

The research has been conducted at a number of sites in six jurisdictions in Canada: Alberta, Nova Scotia, Ontario, Quebec, Nunavut and British Columbia. Alberta was our first site, and has effectively been the pilot for the remaining national jurisdictions.

\section{RESULTS FROM ALBERTA: WHAT THE PARTICIPANTS TOLD US}

Analysis of the research data collected nationally is still underway, however, our initial analysis of the data from Alberta has been completed. ${ }^{16}$ In Alberta, 59 members of the justice community and 20 members of the public who were, or had been, involved in a civil justice case participated in interviews. ${ }^{17}$ At the completion of the Alberta data analysis we were able

1s The short questionnaires, interview guides and other research instruments are available online: Canadian Forum on Civil Justice <iwww.cfcj-fcjc.org/research-cjsp.htm\#4>.

is For other discussions of the Alberta results see Diana L owe \& Mary Stration, "Talking With the Public: The Pubtic, Communication and the Civil Justice System" in Patrick $\Lambda$. Molinari, ed., Dialogues About Justice: The Public. Legislators. Courts and the Media (Ottawa: Canadian Institule for the Administration of Justice, 2002); and News \& Views On Civil Justice Reform 7 (Summer 2004), online: Canadian Forum on Civil Justice <www.cfcj-fcjc.org/issuc_7/CFCJ\%20summer\%202004.pdB [New's \& Views].

17 Because this is an action research project, we keep the door open for additional participation. Recently three more public interviews have been completed and one is also scheduled with a member of the justice community. These new interviews will be included with the national data set. 
to identify six major thematic areas, along with sets of related sub-themes that facilitate the coding and analysis of the full national data. ${ }^{18}$ These major themes are:

1. Modes of communication - Who communicates with the public and with each other within the civil justice system, and how do they do it?

2. Communication experiences - How is communication experienced by the various people (public and justice community) interacting with the system?

3. Communication barriers - What practices are identified as barriers to good communication?

4. Good communication practices - What practices are identified as aiding good, effective communication?

5. The change environment - What is the social context in which change occurs (technology, organizational structure, resources, cultural trends/shifts)? Does the communication context change across time and space? What/who facilitates the occurrence of change?

6. Barriers to change in communication - What factors hinder the process of change?

These themes are rich with information relevant to the main research. questions we presented earlier in this paper. Fully reporting on and responding to all of the implications of this research must be done in the context of a full analysis of the national study and will require many varied forms of dissemination. In this article, we offer an overview of some of the key points made by study participants in Alberta. We present these in the context of the first three research questions, drawing on data from interviews, questionnaires and observations. However as we consider each of our primary questions, it is the actual words of the participants that speak most powerfully in response to the research questions.

\section{WHAT IS THE CURRENT STATE OF COMMUNICATION BETWEEN THE (BROADLY DEFINED) CIVIL JUSTICE SYSTEM AND THE PUBLIC ABOUT BEING INVOLVED IN A CASE IN THE CIVIL COURT SYSTEM?}

A basic point that the data establishes is that most people working within the civil justice community are involved either directly or indirectly in communications between the civil justice system and the public. It is interesting to recognize that those within the justice community who are least likely to communicate directly with the public on a regular basis (that is, senior management in all areas of the civil justice system) are often those most themes that were shared with our project partners. These are reported in News \& Views, swpra note 16 at 8. Upon completion of the full Alberta analysis considerable overlap was identified among some themes. As a result the various components of the original themes were reorganized into six areas with stronger thematic and analytical power. Full descriptions of both sets of themes are available from the Forum upon request. 
responsible for deciding policies that impact the conditions under which the public and front line workers do communicate.

It is also apparent that people working on the front lines of communication between the system and the public often do so under difficult conditions for several interrelated reasons. First, there are frequently insufficient resources to meet the level of demand from the public. This tends to lead to understaffing, work overload and a lack of appropriate training, especially training on how to most effectively communicate with the public. This situation is exacerbated because the valuable knowledge front line staff gain from daily interactions with the public is habitually overlooked by those planning systemic changes and reforms. In fact, the quantitative evidence suggests that the importance of the work court clerks do is systemically undervalued. Certain income and education levels are attached to various kind of work and are demographic indicators of the social value afforded that work. In Alberta, court clerks reported the lowest levels of education and the lowest family incomes of all participant groups. ${ }^{19}$

Data from the questionnaires also show, however, that court clerks are a key sources of information for members of the public who become involved in a civil justice matter. As Table 1 illustrates, when the need arises the public attempt to find out about and communicate with the civil justice system by any method available to them, and courthouse staff are a primary information source. When all of the information sources involving the courthouse are considered together, the importance of front line staff at this site is underscored. ${ }^{20}$

TABLE 1: WIERE TIE PUBLIC I,OOK FOR INFORMATION

\begin{tabular}{|l|c|}
\hline \multicolumn{1}{|c|}{ SOURCE OF INFORMATION $(\mathrm{N}=19)$} & USED BY PUBLIC $\%$ \\
\hline Lawyer & 100 \\
\hline Friends & 77 \\
\hline Family members & 70 \\
\hline Court administrative staff & 62 \\
\hline Court information desk/kiosk & 58 \\
\hline Public legal education pamphlets/booklets & 58 \\
\hline Police services & 54 \\
\hline Government department & 50 \\
\hline Co-workers & 42 \\
\hline The Internet & 42 \\
\hline Public legal advice telephone line & 42 \\
\hline Legal Aid Society & 36 \\
\hline Signs \& directions in the courthouse & 36 \\
\hline Law Library & 33 \\
\hline
\end{tabular}

$14 \quad$ Our sample was small and non-random. Our figures can only be seen as possible indicators of trends that exist and are worthy of further investigation.

20 A further 8 percent of participants reported seeking information from security officers. Our observations suggest this figure to be rather low as the security officer tends to receive the initial inquiry as to where other sources of information (including the appropriate counter or courtroom) are located. 


\begin{tabular}{|l|c|}
\hline \multicolumn{1}{|c|}{ SOURCE OF INFORMATION $(\mathrm{N}-19)$} & USED BY PUBLIC $\%$ \\
\hline Public legal information session/workshop & 33 \\
\hline Radio news/information show & 33 \\
\hline Public library & 25 \\
\hline Notice boards in the courthouse & 25 \\
\hline Newspaper articles & 17 \\
\hline Television news/information shows & 17 \\
\hline Television dramas & 17 \\
\hline School class/program & 17 \\
\hline
\end{tabular}

In terms of the preferred ways to communicate, both public and justice community participants expressed a strong preference for face-to-face communication whenever possible as they found it to be most effective. However, when face-to-face communication is impossible, our participants recommend two alternatives:

a) a telephone line that reaches a person who is able to provide comprehensive information, and/or

b) an accurate, comprehensive, but easy to navigate Web site.

Telephone lines tend to be favoured in rural and remote communities that serve large surrounding areas. In these circumstances, the presence of a physical multi-service information centre does not address the challenge of providing effective information across vast distances. More remote areas are also less likely to have reliable Initernet access, a factor that sometimes applies to the justice community as well as to members of the public.

Overall, the study data indicate that the current state of communication between the civil court system and the public can be improved. There are communication barriers to overcome, but also many examples of good communication practices to draw from and build upon, both in Alberta and across Canada. In particular, we were repeatedly told by both the public and the justice community that there is a need for better public information about the civil justice process. Addressing this concern requires a focus on three key areas:

1) the public need to know where to find existing legal information;

2) clear, accurate legal information must be created to fill identified information gaps (for example, steps in the process of litigation); and

3) the public need to be able to obtain, at minimum, basic legal advice at key points in the civil justice process.

There is a strong foundation of agreement about these needs on which to build responsive action, but as we now amplify, finding ways to do so effectively is undeniably challenging within the complexities of the civil justice system.

\section{a. Finding existing legal information}

Many of our public participants readily admitted that they had little or no prior knowledge about how the civil justice system worked and they did not really know what to do to find out. As one participant explained: 
[ mean, right now, if I had a problem with my neighbour and I have done everything I can possibly do to work it out, what do I do next? Do I take it to court? Do I need a lawyer? Can I just walk in there and represent myself?

Talking now about her own experience of involvement in a family case, the same participant explained some of the information seeking process indicated by Table 1:

If I hadn't had a triend who had a name of a good lawyer, I don't know where I would have gone to. I was in the Yellow pages, but you've got how many hundreds of lawyers? What do you do? Just close your cyes and point?

Another participant underlined the problem of finding needed information:

\begin{abstract}
I had no clue as to how things were set up before I actually got into trouble and had to do something. I initially asked my friends ... then asked people ... who had been involved.... Then there was a service in town called "Dial-at-lawyer" or something and there were three people I talked to who were helpful... I went to the police station. They also agreed it wasn't my fault but laughed and said "good luck getling your money."... If you don't know where to start, you don't know the questions to ask and if no one is giving you the answers to the questions you don't ask you are not going 10 lcarn new stuff.
\end{abstract}

We have learned from our justice community participants that they are also often unaware of valuable sources of information that do exist, or sometimes they know about a useful information item but don't know where it can be found. This obviously hampers effective communication with members of the public seeking information and underlines a need for improved information sharing mechanisms within the civil justice system. ${ }^{21}$ As the following participant suggests, there is a need for networking:

[Among] the civil justice system itself might be helpful ... meeting between the various levels... The lowlier type of employees don't have an opportunity to interact with people in other cours.... Some kind of opportunity to ... spend a half day, or a couple of hours ... and see how the program runs.

\title{
b. Providing clear and accurate legal information
}

Finding a source of relevant information is only a first step for the public in the process of understanding the civil justice system. Our public participants told us that they needed information that was clear and easy to follow. They complained about receiving information that was outdated, contained too much "legalese," and that failed to give concrete step by step instructions about what they needed to do. In particular, participants (including many working in the justice community) pointed to a need for information that guides litigants through the steps in the process of litigation, especially concerning how to complete and file forms. They offered the following observations and suggestions:

" As we have begun the focus group process in Alberta, both the existing gaps in information sharing and the desire of the justice community to establish better networks tor knowledge exchange have been underlined. We have discussed this issue further in New's \& lieu's, supra note 16 at 4-7. 
I think the general public have got to better understand how the system works and we have to assist in helping them.... We have to try to make it simpler ... in plain language - not so technical.... And then ... there should be a broad information project to the general public indicating that they can get information [in] these various [ways], but that means the [ways] have to be set up. You have to develop them and then do the PR.

Filling out forms ... that was probably the most difficult thing "cause I had no clue how to do it... I talked to a law clerk and she helped me go through how it should be filled out. Because they are very vague sometimes ... an example [would help]. Just give me something to base it on because if they're not done right you may as well throw them in the garbage and start again.

Basic commencement needs. How to commence a civil claim document and how to proceed with that type of thing.... We [Court Clerks] repeat the same thing 100 times a day - that would be a minimum. Huge. Even though the booklet's on the stand, even though they have access to the Internet, even though they've come down and talked to a clerk at the counter - they're still phoning. The same people are still phoning. To be honest ... if you've never done it and you've never had a legal issue, there is just nowhere to access that information.

I think ... most people writing the pamphlets are university educated.... I talk to my husband ... he's university educated - about the law. I think I am talking normal general language and he doesn't understand a word I am saying. I think, "Oh, my gosh, I sometimes talk to my clients like that!" I have to make sure they understand. If my husband can'l understand, how are my clients going to? The simple language ... plain language in law - we really need a lot of that in the pamphlets and the administrative stuff. When you see the forms that they make in the courthouse for people to fill out, number one it says "Affidavil" - did you

know what that meant before law school?

\section{c. Access to basic legal advice}

The availability of good information about the civil justice system and the litigation process is essential, but not always sufficient to ensure full access to justice for the lay person. Members of the justice community generally agree that access to legal advice is preferable and should be available. Most of the self-represented litigants in our study would have preferred to be able to access good legal advice, at least at some points in the process. A court manager and a public participant, respectively, both extolled similar points of view on the need for available legal advice:

It would be nice to have a lawyer on site for these people, because that is what they are wanting. $\wedge$ lot of it is legal advice and we can't help them.... A duty lawyer to help ... on civil claims day ... [and] it would be wonderful to have a lawyer for family court day.

Legal Aid was very helpful to me. When I went down, the lady that I talked to ... set me up with a lawyer. I could go down and talk to him for an hour and that would help me out. She said he would give me all the information I would need even though I might not use him.... It was a big help to me because he was the right person to talk to because it was all confidential.... Even though 1 may not use him [in court] he can tell me, Okay, you can write this down and he can tell me how to represent myself.... [But] I am hoping I can get a lawyer. 
The reality, however, is that many people can either not afford, or cannot find a lawyer. ${ }^{22}$ The financial criteria cut off for Legal Aid is low and even when financial eligibility is present, Legal Aid is not available for most civil matters. Family and civil duty counsel and/or pro bono services are available in some jurisdictions. Our public participants generally spoke positively about such services when they had accessed them. However, those that exist are overextended and currently the exception rather than the rule.

2. HOW IS THE COMMUNICATION EXPERJENCED: A) BY PEOPLE WITHIN THE SYSTEM (WITH EACH OTHER AND WITH THE PUBLIC) AND B) BY THE PUBLIC?

The general state of communication within the civil justice system and between the system and the public obviously impacts the experiences of those attempting to communicate within it. In understanding communication experiences, it is important to think about the contexts and conditions within which they take place. The civil justice 'system' is actually made up of a number of separate structures that are hierarchically organized, both internally and in relation to each other. Many interactions are highly technical and formalized. Some of these arrangements are necessary to preserve fairness and impartiality. Nevertheless, these hierarchical (and sometimes adversarial) communication customs create communication barriers among those working within the justice community as well as between the system and the public.

Particularly unfortunate is that the front line experience of those who interact daily with the public is often not sufficiently valued, and frequently overlooked by those further up the hierarchy who are responsible for initiating change within the system. As one legal services participant told us:

\footnotetext{
There is a real lack of confidence among most of the employees as to whether the [Board of Directors] really have a clue what we are doing.... Do they really know that ... in a day in the office you would probably be interviewing 14 people on very complicated civil issues? ... The staff feel that firstly, management is not very aware. They are a little bit aware because they hear us freaking out once in a while. The Board of Directors is completely unaware.
}

This kind of disjuncture between front line experience and management's understanding of it leads to initiatives for policy and practice changes that do not actually work well at the front line and also contributes to the kind of information gaps already discussed above. A court staff member summed up what needs to be done to address this situation:

Administrators need to be responsible for informing their staff on projects, programs, changes and there has to be an openness within the system to take an interest in changes.

Front line staff must communicate with the public under difficult circumstances. Members of the public come into personal contact with the civil justice system when they have a legal

$22 \quad$ People in rural and/or remote areas are less likely to be able to find a lawyer regardless of their ability to afrord one. Hiring a lawyer from a distant city increases both expense and potential communication barriers. 
problem that is already generating stress. They find the formality and complexity of the civil justice system confusing, even when they have legal representation. Many express frustration about their experience of communicating with the system. Lack of clear information exacerbates the problem and the fine line between legal information and legal advice is difficult for the lay person to understand. For litigants who represent themselves the experience can be overwhelming as one participant commented:

I walked into this resource centre and I fell like crying ... the employees there had no idea what had happened to me and what I was feeling and what I was going through.

But, positive responses from the justice community can make a difference, as the same participant continued to explain:

J just walked through the door and the [stam] said 'Hi.' Like they were just so positive and it just washed away what I had expericnced [just before]."

All of our public participants found their interaction with the civil justice system at least a somewhat emotionally stressful experience, but when an individual is in an especially vulnerable situation, negotiating the system in an attempt to find justice can be entirely frightening. The following extract is from an interview conducted with an immigrant woman via the interpretation of a friend who was trying to help her through the legal process. ${ }^{23}$ The participant had been served divorce papers by her husband just after she had returned home from hospital following a Caesarean birth.

I: She cried from morning until night ... on that day her husband gave her the papers, both the husband and the fatler came ... and said, "go sign these papers." She didn't want to. She refused.... Then she phones me erying. She said, "I have no idea what to do." So I called the police. What should we do? I was so worried that they would turn violent to her, but they didn't. The police said, if she doesn't want to sign, stic doesn't have to sign.... [It] was Saturday — I couldn't reach anybody ... Monday then I contacted ... Emergency Social Services Group and they were the ones who told me to go to Legal Aid.

P: [Via the interpreter] without translation I cannot go — cannot do anything ... I could have called [Country] consulate, but then help ... it's in [another city]. How fast does help come? lt's a very long time ...

I: I can't remember who I contacted, but there was somebody who gave me information ... "we will give you three lawyers and you can have halr hour with them." I never called them though because after half-hour you have to pay. She doesn't have moncy. So that was very confusing for me ... Yeah, to tell you the truth, for me, who speaks English, it was kind of confusing. Where 1 go for help for somcone who has no money? But, whose husband is asking her, "sign these papers and get your own lawyer." And, "pay for it yourself."

P [ 1 say] where money for pay lawyer? [He say] "You have money." Where I have money for I, daughter? "I don'I know, I don't care." 
I: ... Here she never has money. Not for a lawyer. She has to have a bank card but there is a limited amount in there ... and she always has to ask his permission to use it... That advice that I got that you go and get half an hour with three lawyers ... I went through the telephone system - they say punch this number and that number for more information. It's confusing for someone who doesn't speak English. Even for me. I was hesitant to - 1 never called those three lawyers to get half an hour from them ...

P: [Whisperingl

R: You think he's going to come [here]? OK [Interview terminated]

\section{WHAT CAN BE DONE TO IMPROVE COMMUNICATION BETWEEN THE CIVIL JUSTICE SYSTEM AND THE PUBLIC?}

Although there are real challenges to meet, many things can be done to improve the state of communication between the civil justice system and the public. Some require more resources than are currently available, but others can be achieved simply by increased awareness and making better use of resources already in existence. Sharing communication perspectives and experiences is an important first step in increased awareness and understanding of communication issues. Participants from both the public and the justice community have provided many good suggestions to work from. Two members of the judiciary, respectively, offered a general formula to start a process of constructive change:

My recommendations would be: 1 . Work on gaining more resources; 2 . Deal with the attitudes of decision makers; 3. Use expertise in communications and a multidisciplinary approach.

Decide who it is we are trying to reach with our information.... Talking to people within your court. Assessing their needs ... where they might be better served if there was better information out there. For that you need strong leadership ... intuitive front line workers and a medium in which you can all communicate and meet together to try to ... meet the needs that you see.

Other justice community participants identified specific areas of change that would lead to improved communication with the system:

First of all, for the civil justiec system to be informed about each other so when we are ... trying to help the public we know what we are talking about.

[There needs to be] one place where at least the information on all services is located ... [and] work with the gatckeeper lawyers, the people who initially see people, on how to disseminate this information.

Some kind of a clinic set up with lawyers that can at least give people some basic legal advice ... should be a number one priority ... court time and ... money would end up being saved.

More time for education or the training component and for the slaring of information.

A training program for [Legal Aid] to be able to communicate with the lay person as far as reading forms and trying to help them understand their ordets or their documents. 
[A] comment box, an area or avenue that they [public and court staff] can use to ... express their ideas on how to improve [communication].

Public information officers ... to assist the court in three areas ... developing better lines of communication with the media; ... the education of students ... in our high schools; ... [and] to deal with the public generally; to develop techniques for communicating information accurately and effectively, both outgoing information and to deal with information that is coming in.

Public participants also had suggestions for improving communication and the flow of information to the public:

In terms of communication, 1 would say the website, the [multi-service] kiosk ... would be fabulous, and improved access to legal advice.

Case law.... Quick Law and other services like that ... your average layperson can tap into and find valuable information ... on-line ... readily accessible.

Brochures more layman like.... "Cause you read through it and you go, "What does that mean?" ... They all have that lawyer-talk lingo ... and for somebody who hasn't been there it is difficult to understand.

Members of the justice community have tended to point out that the literacy and research skills required to utilize materials such as those suggested above are relatively high. The availability of one-on-one assistance for members of the public who face literacy barriers is essential. It must always be remembered that there are additional challenges in accessing and using the civil justice system for some groups of public (for example immigrants, Aboriginal persons and persons with disabilities). Nevertheless, our research revealed a group of welleducated self-represented litigants who can, and do, conduct successful research into presenting a civil case. Other community and social service workers would also benefit from improved access to the kind of information tools suggested by our participants. Given the evidence that members of the public tend to turn to personal contacts for initial help when confronted with a civil justice issue (see Table 1), it would seem important to ensure full access to information for those in a position to help others. Furthermore, we learned that represented litigants sometimes also want to better understand the legal process and decisions in their case, but as one participant told us interest in doing so is not always encouraged:

My lawyer was amazingly helpful ... he was on my side, but he was identical to everybody else.... So really you have no idea what is going on.... You calt the lawyer maybe once every two weeks. He gives you a three or four sentence update ... You are not included at all ... When you do hire someone who is in the system, they are kind of like, "We know how this is going to work. The reason I look the case is I agree that you are right, but just go away and answer the questions I have for you." You are totally removed from the whole process.... So, there is no real understanding. I'm not sure if I am more informed now than $I$ was before.

\section{IMPLICATIONS FOR CHANGE}

The results in Alberta contain implications for change, but it is premature to offer concrete recommendations before the analysis of the entire study is completed. We do know, based on the Alberta results and preliminary review of the national data, that the final 
recommendations will address issues relating to hierarchy, the need for training and the creation of court user committees with representatives from throughout the justice system and the public. These recommendations will evolve from the research data from all six jurisdictions; focus groups held in the research jurisdictions, which will help us to identify how the community can act on our findings; case studies of examples of good communication practices; and feedback from our justice community partners.

Our goal is to provide concrete solutions that will lead to measurable improvement. Toward that end, we are already working with the justice community across Canada. Our research has helped increase awareness of communication as a concept on which the justice community must focus, and we have already evidence that there is strong interest in applying the study results in movement towards change. As one participant stated:

The courts are becoming, and rightly so, more conscious of their responsibility to communicate with the public, to tell the public what is happening in justice, to explain what we do and, in some respects, why we do it.... We need to do that more and better and we are looking for ways to do that.... One of the things I think we need to do is ask the public what they know about justice... We need to do a sort of needs survey.... What would they like to know? What do they need to know? And, how can we get that information to them?

This participant points to a need to find the resources for ongoing research that furthers the understanding between the system and the public. We believe that our research is helping to shape and encourage the move toward increased evidence-based research in law, the importance of which has received recent international attention. ${ }^{24}$ In order to encourage ongoing research on our civil justice systems, we are working closely with academics from law and the social sciences, as well as with the justice community, to promote the development of research expertise in this area of vital social interest and concern. Researchers will be encouraged to become engaged in research priorities including: the gathering and evaluation of existing evidence-based research in the area of civil justice in Canada; specific reform initiatives; the development of sociological theory of the organization and process of civil justice; the implication of the cultural turn in the social sciences for research in law; the ways in which the law figures in empirical social research; the need for rigorous, multi-method program evaluation; fundamental issues of public participation, public information and education; and improved understanding of the role that our civil justice system plays in our society, economy and polity. Most importantly, we will continue to work with the civil justice community in order to bring about positive change that leads to increased access to justice for members of the public.

24 See the Inguiry on Empirical Research in Law: Consultation Document, April 2004, online: University College of London, Faculty of Law <www.ucl.ac.uk/laws/genn/empirical>. 